\title{
UNFAIRNESS DOCTRINE I PODEJŚCIE EKONOMICZNE DO OCHRONY KONSUMENTÓW W PRAKTYCE FEDERALNEJ KOMISJ HANDLU W USA
}

\begin{abstract}
WSTĘP
Federalna Komisja Handlu (Federal Trade Commission - FTC) jest instytucją administracyjną - niezależną agencją rządu federalnego, odpowiedzialną przed Kongresem - o bardzo szerokich uprawnieniach. Pełni ona funkcje zarówno prokuratorskie, jak i rozstrzygające w sprawach indywidualnych, a także - do pewnego stopnia - prawotwórcze ${ }^{1}$.

Ustawa powołująca Federalną Komisję Handlu: Federal Trade Commission Act $1914^{2}$ zakazała "nieuczciwych metod konkurencji” (unfair methods of competition - sect. 5 FTC Act 1914).

Sformułowanie sect. 5 FTC Act 1914 określające jako nielegalne „nieuczciwe metody konkurencji” okazało się jednak w praktyce niewystarczająco jasne do zwalczania nieuczciwych praktyk rynkowych, szczególnie takich, które nie zagrażały mechanizmowi konkurencji. Dotyczyło to np. nieuczciwej reklamy. W roku 1931 Sąd Najwyższy ograniczył kompetencje Federalnej Komisji Handlu w sprawach reklamy, stwierdzając, że reklama nie stanowi „metody konkurencji”, gdy brak konkurentów w danej dziedzinie ${ }^{3}$. To niefortunne ograniczenie zbiegło się

1 http://ftc.gov/; patrz też: T.J. Muris, R. Pitofsky, More than Law Enforcement: The FTC's Many Tools - A Conversation with Tim Muris and Bob Pitofsky, „Antitrust Law Journal” 2005, vol. 72, No. 3, s. 773 i n.

2 W aktualnej wersji: 15 U.S.C $\S \S 41-58$.

3 FTC v. Raladam, Co., 283 U.S. 643 (1931). W tej sprawie FTC zakazała producentowi leków reklamowania swojego środka przeciw otyłości jako skutecznego, gdyż posiadał on właściwości w pewnych przypadkach szkodliwe dla zdrowia. Decyzja FTC została odrzucona przez Sąd Apelacyjny, a następnie przez Sąd Najwyższy, który stwierdzil, że Komisja nie jest władna rozstrzygać tej kwestii, jako że nie było innych sprzedawców takich środków, a zatem reklama ta nie stanowi metody konkurencji - podaję za: J. Miller, Unfair Competition, Cambridge 1941, s. 53-72.
\end{abstract}


w czasie ze skutkami kryzysu, narastającą krytyką negatywnych zjawisk gospodarczych i praktyk rynkowych stosowanych przez przedsiębiorstwa oraz żądaniami wprowadzenia regulacji chroniącej interesy konsumentów.

W tej atmosferze, kolejna ustawa: Wheeler-Lea Act 1938, aby rozstrzygnąć wątpliwości interpretacyjne, wprowadziła poprawkę do sect. 5 FTC Act 1914, która rozszerzyła zakres tego przepisu, uznając za nielegalne „nieuczciwe metody konkurencji w handlu i nieuczciwe lub oszukańcze (wprowadzające w błąd) dzialania lub praktyki handlowe"4 (unfair methods of competition in commerce, and unfair or deceptive acts or practices in commerce); po kolejnej poprawce, wprowadzajaccej uzupełnienie „lub wywierające wpływ na handel” aktualnie obowiązująca formuła brzmi: Unfair methods of competition in or affecting commerce, and unfair or deceptive acts or practices in or affecting commerce, are hereby declared unlawful ${ }^{5}$.

Prawotwórcza działalność FTC polega na opracowywaniu i publikowaniu zasad regulujących handel i marketing (trade rules) dla wybranych towarów i usług (np. artykułów i usług optycznych, usług pogrzebowych) lub w wybranych dziedzinach (np. w handlu wysyłkowym, sprzedaży kredytowej). Wynika ona z kompetencji, jakich prawo stanowione udziela Komisji w zakresie wypełniania treścią pojęcia „nieuczciwe praktyki handlowe” oraz ustalania ogólnych zasad postępowania w odniesieniu do nieuczciwych lub wprowadzających w błąd działań czy praktyk. Ustawa Magnusson-Moss 1975 formalnie wyposażyła FTC w kompetencje tworzenia i wprowadzania zasad regulujących handel oraz określania rodzaju praktyk zakazanych, sankcjonując wcześniej już prowadzoną działalność Komisji w tym zakresie 6 . Wprawdzie działalność ta została częściowo ograniczona przez kolejną ustawę uzupełniającą - FTC Amendments Act 1980, która wprowadziła szereg ograniczeń proceduralnych ${ }^{7}$, a każda zasada wprowadzona przez Komisję może zostać zakwestionowana przez Sąd Apelacyjny (US Court of Appeal), niemniej jednak regulacje przyjmowane przez FTC jako doprecyzowanie ogólnego

4 Biorąc pod uwagę szerokie znaczenie terminu „commerce”, pojęcie to może być traktowane jako odpowiednik „nieuczciwych praktyk rynkowych”.

5 The Federal Trade Commission Act 1914, 15 U.S.C. § 45a; http://www.stolaf.edu/people/ becker/antitrust/statutes/ftc.html.

6 Do 1975 r. w niektórych orzeczeniach sądowych kwestionowano formalnoprawne znaczenie takich regulacji (por. np. stanowisko sądu w sprawie: National Petroleum Refiners Assoc. v. FTC (1972), szerzej: D. Cohen, Remedies for Consumer, Protection: Prevention, Restitution or Punishment, "Journal of Marketing” (dalej: J. of M.) 1975, No. 4, s. 24). Faktycznie jednak już wtedy wywierały one znaczny wpływ na praktykę postępowania.

7 O ile wcześniej (na mocy Magnusson-Moss FTC Improvement Act 1975) regulacja wydana przez Komisję publikowana była automatycznie w „Federal Register” i na czwarty dzień po publikacji wchodziła w życie, to na mocy ustawy zmieniającej z 1980 r. Kongres uzyskał uprawnienie wniesienia w ciągu 9 dni weta w stosunku do przyjętej przez Komisję regulacji; ponadto ustawa wymaga odpowiedniej wcześniejszej procedury, m.in. opublikowania propozycji regulacji, powiadomienia Senatu itp. - Federal Trade Commission Improvement Act 1980, § 21, 15 U.S.C. § 57a-1 (c). 
pojęcia unfair or deceptive acts or practices $\mathrm{w}$ poszczególnych branżach mają moc prawną i duże znaczenie praktyczne ${ }^{8}$.

W ciągu kilkudziesięciu lat, jakie upłynęły od wprowadzenia zakazu nieuczciwych lub oszukańczych działań lub praktyk handlowych, stał się on podstawą do zwalczania przez Komisję szerokiego zakresu praktyk szkodliwych dla konsumentów. W zakresie tym znalazły się przede wszystkim zagadnienia nieuczciwej reklamy i wszelkiej wprowadzającej w błąd informacji o towarze, warunkach sprzedaży, udzielanych gwarancjach itp. Komisja zajmowała się szczegółowo różnymi aspektami problemu, np. reklamą mającą na celu wyłącznie przyciągnięcie konsumenta po to, aby następnie przerzucić jego zainteresowanie na inny towar; mylącymi porównaniami cenowymi; wprowadzającą w błąd promocją za pomocą bezpłatnych dodatków (tzw. free offer). $Z$ biegiem czasu zakres działań Komisji w dziedzinie ochrony konsumenta ulegał rozszerzeniu, obejmując coraz to nowe zagadnienia i formy działalności rynkowej.

Jakkolwiek zatem u podłoża powołania FTC w roku 1914 leżała potrzeba stworzenia instytucji o szeroko zakreślonych kompetencjach w zakresie egzekwowania ustaw antytrustowych, mających na celu ochronę modelu konkurencji, w szczególności przeciwdziałanie postępującym procesom monopolizacji produkcji i handlu, współcześnie akcentuje się rolę Federalnej Komisji Handlu jako instytucji o najszerszych uprawnieniach w sprawach ochrony konsumenta ${ }^{9}$.

\section{ROZWÓJ UNFAIRNESS DOCTRINE NA PODSTAWIE ZAKAZU WPROWADZAJĄCYCH W BŁĄD LUB NIEUCZCIWYCH PRAKTYK RYNKOWYCH}

Komisja jest władna uznać daną praktykę za wprowadzającą w błąd (deceptive) lub nieuczciwą (unfair).

$\mathrm{Z}$ biegiem czasu ulegała sprecyzowaniu, a równocześnie stopniowemu rozszerzaniu interpretacja wprowadzenia w błąd (deception). Już na początku lat siedemdziesiątych XX w. Komisja przyjęła tzw. zasadę racjonalnej zasadności twierdzeń w działalności marketingowej (substantation of claims), zgodnie

\footnotetext{
Szerzej: How the FTC brings an action, http://www.ftc.gov/pbc/conline/pubs/general/ guidetoftc.shtm.

9 Według dokumentów samej FTC, jej główną misję współcześnie stanowi „promocja ochrony konsumenta i eliminowanie antykonkurencyjnych praktyk biznesowych oraz przeciwdziałanie takim praktykom" - http://ftc.gov/ Zadaniom Komisji podporządkowana jest jej struktura organizacyjna. W ramach Komisji działają trzy biura: Biuro Ochrony Konsumenta (Bureau of Consumer Protection), Biuro Konkurencji (Bureau of Competition) i Biuro Ekonomiczne (Bureau of Economics).
} 
z którą obowiązek udowodnienia prawdziwości twierdzeń reklamowych spoczywa na ich nadawcy, a wszelkie twierdzenia, których prawdziwość nie może zostać udowodniona, uważa się za nieuczciwe (unfair). Podstawa nieuczciwości tkwi, zdaniem Komisji, w przerzuceniu na konsumenta ryzyka związanego $\mathrm{z}$ brakiem racjonalnej, uzasadnionej podstawy podawanej informacji. Przyjęcie tej zasady, wówczas nowatorskiej, uzasadniano tym, że „z punktu widzenia ekonomicznego racjonalniejsze i oszczędniejsze jest żądanie od nadawcy potwierdzenia zasadności jego stwierdzeń zachwalających towar, niż obarczanie ciężarem badania lub eksperymentowania na sobie przez każdego indywidualnego konsumenta"10.

Wcześniej też niż w Europie uznano, że brak w ogłoszeniu reklamowym istotnej informacji może stanowić o uznaniu go za wprowadzające w błąd, mimo że ogłoszenie nie zawiera stwierdzeń o fałszywych faktach. W konsekwencji za oszukańczą lub wprowadzającą w błąd (deceptive) reklamę przyjęto uważać: reklamę fałszywą - gdy zawiera dane obiektywnie sprzeczne z prawdą; reklamę wieloznaczną - gdy jedno z możliwych znaczeń jest nieprawdziwe lub częściowo nieprawdziwe (np. poparte fałszywym dowodem), albo jeśli ogłoszenie, formalnie zgodne $\mathrm{z}$ prawdą, wywołuje fałszywe wrażenie; a ponadto - reklamę niedostatecznie informującą, która ukrywa istotne dla konsumenta dane o towarze, np. dotyczące zasadniczych ograniczeń w jego użyteczności. Miernikiem istotności informacji jest jej wpływ na wybór dokonywany przez konsumenta lub jego postępowanie $^{11}$.

Kryterium nieuczciwości (unfairness) jest ogólniejsze niż kryterium wprowadzenia w błąd (deception) i może być podstawą stwierdzenia nielegalności znacznie szerszego zakresu praktyk niż kryterium wprowadzenia w błąd. Przykładowo: przyjęcie kryterium unfairness doprowadziło w latach 70. do coraz szerszego

10 W sprawie dot. reklamy środka przeciwbólowego: in re Pfizer Inc., podaję za D. Cohen, The Concept of Unfairness as it relates to Advertising Legislation, J. of M. 1974, No. 3, s. 9; na tej podstawie w grudniu 2010 r. Komisja zakwestionowała reklamy firmy Dannon (w Polsce znanej jako Danone) głoszące, że jogurty Activia wspomagają regularne funkcjonowanie przewodu pokarmowego, a napój DanActive podnosi odporność organizmu, uznając, że nie ma wystarczających danych naukowych na poparcie takich twierdzeń (w wyniku ugody firma Dannon zgodziła się wypłacić $21 \mathrm{mln}$ dol. tytułem odszkodowania).

11 Por. decyzje FTC jeszcze z lat 70. ubiegłego wieku, np. w sprawach: Medi-Hair International, March 1972, w: Legal Developments, J. of M. 1972, No. 4, s. 69; Hair Replacement Centers of Boston, May 1976; w: Legal Developments, J. of M. 1977, No. 1, s. 96; Kensec Sport Inc., April 1972 - podaję za: D. Cohen, The Concept of Unfairness, s. 10; patrz też: K.T. Brandt, J.L. Preston, The Federal Trade Commission's Use of Evidence to Determining Deception, J. of M. 1977, No. 1, s. 54 i n.; J. Boddewyn, Advertising Regulation in the 1980's: the underlying Global Forces, J. of M. 1982, No. 1, s. 27 i n.; L.W. Stern, T.L. Eovaldi, Legal Aspects, of Marketing Strategy, Antitrust and Consumer Protection Issues, Englewood Cliffs, New Jersey 1984, s. 371-374 oraz G.T. Ford, J.E. Calfee, Recent Developments in FTC Policy on Deception, J. of M. 1986, No. 2, s. 39-92. 
uznawania za niedozwoloną reklamy przesadnej (puffing claims), czyniącej nierealne obietnice (tradycyjnie $\mathrm{w}$ prawie powszechnym przyjmowano zasadę dopuszczalności reklamy typu puffing pod warunkiem, że przesada jest oczywista dla odbiorcy). Uznając, że „uczciwość wobec konsumenta” wymaga uwzględnienia specyfiki ochrony grup konsumentów szczególnie wrażliwych - Komisja posłużyła się argumentem nieuczciwości np. w celu zakazania reklam, które mogą naprowadzać dzieci na niebezpieczne zachowania (przedstawiające np. dziewczynkę suszącą lalce włosy elektryczną suszarką). Kryterium nieuczciwości dało podstawę do uznawania za nieuczciwą praktykę i zakazywania narzucania konsumentom warunków wyrażnie naruszających równowagę praw i obowiązków stron („rażąco nieuczciwych”, „narzucanych bez skrupułów” ${ }^{12}$.

Lata 70. XX w. w praktyce Federalnej Komisji Handlu cechuje rozwój tzw. doktryny (nie)uczciwości wobec konsumenta - unfairness doctrine, zapoczątkowanej precedensowym orzeczeniem Sądu Najwyższego (US Supreme Court) z roku $1972^{13}$, w którym Sąd stwierdził, że konsument, podobnie jak producent i kupiec, winien być chroniony przed nieuczciwymi praktykami rynkowymi, a Komisja może uznać daną praktykę za nieuczciwą, mimo że nie narusza ona litery ani ducha prawa antytrustowego.

Równocześnie jednak pojawiły się wątpliwości interpretacyjne. Faktycznie Sąd Najwyższy nie zdefiniował nieuczciwości; w uwagach do orzeczenia przytoczył jedynie subkryteria, wcześniej już sformułowane przez samą Komisję ${ }^{14}$, które scharakteryzował jako „dostateczne, ale niekonieczne” dla stwierdzenia nieuczciwości: 1) naruszenie interesu publicznego (gdy praktyka, niekoniecznie uznana wcześniej za nielegalną, narusza prawnie usankcjonowany interes publiczny, 2) niemoralność (gdy praktyka jest nieetyczna, uciążliwa lub niegodziwa), 3) wyrządzenie szkody (gdy praktyka powoduje wyrządzenie istotnej szkody konsumentom, konkurentom lub innym uczestnikom obrotu).

12 Por. informacje w stałej rubryce pt. Legal Developments in Marketing, J. of M., różne numery z lat 70.XX wieku. Warto zwrócić uwagę właśnie na wyprzedzenie czasowe w stosunku do Europy, gdzie analogiczne regulacje pojawiły się znacznie póżniej (niektóre wprowadzone dopiero dyrektywą o nieuczciwych praktykach handlowych z 2005 r.).

13 W sprawie FTC v. Sperry EHHutchinson Trading Stamp Co., 405 U.S. 233, 1972.

14 W regulacji dotyczącej sprzedaży wyrobów tytoniowych - FTC Trade Regulation Rule o the Prevention of Unfair o Deceptive Acts or Practices in the Sale of Cigarettes, 1964, 29 Fed. Reg. 8325, 8355. 


\section{PODEJŚCIE EKONOMICZNE DO OCHRONY KONSUMENTA W PRAKTYCE FEDERALNEJ KOMISJ HANDLU}

Pod wpływem ostrej krytyki, w wyniku polemik i sprzeciwów ze strony Kongresu w latach $80 .{ }^{15}$, Komisja zrezygnowała ze stosowania kryterium niemoralności, a miernik „interesu publicznego” przyjęła jako wtórny w ocenie prawidłowości kwalifikacji szkody. Pierwszoplanową rolę w określeniu „nieuczciwości” przyznano tym samym kryterium wyrządzenia szkody. Jednocześnie określone zostały przesłanki decydujące o tym, co uważane jest za „wyrządzenie szkody konsumentom" (consumer injury). Szkoda taka ma być: 1) istotna, 2) nie do uniknięcia mimo rozsądnego postępowania konsumentów, oraz 3) nierównoważona równoczesnymi korzyściami dla konsumentów lub dla konkurencji w ogóle. Warunki te mają obecnie charakter ustawowy ${ }^{16}$. Trzeci z wymienionych warunków zakłada przeprowadzenie przez Komisję analizy kosztów i korzyści (cost-benefit test) w celu zdecydowania o zakazie określonej praktyki jako nieuczciwej.

Jedna $\mathrm{z}$ pierwszych takich analiz przeprowadzona została $\mathrm{w}$ postępowaniu przeciwko International Harvester Corp. (1984). Problem polegał na tym, że w produkowanych przez tę firmę traktorach zdarzał sie wyciek gorącego paliwa na zewnątrz, przy czym przypadki te były na tyle rzadkie, że brak informacji ostrzegawczych nie stanowił wprowadzenia w błąd (deception). Komisja po przeprowadzaniu porównania kosztów informacji ze stratami, których pozwoliłaby ona uniknąć, zakwalifikowała niepodanie informacji ostrzegawczych jako nieuczciwe ${ }^{17}$.

W konsekwencji jednak wymóg przeprowadzania szczegółowej analizy kosztów i korzyści wprowadził w latach 80. istotne ograniczenie zakresu stosowania koncepcji „nieuczciwości”, zarówno w sprawach indywidualnych, jak i - co szczególnie istotne - $\mathrm{w}$ zakresie tworzenia reguł postępowania (trade rules).

Zasady polityki Komisji w zakresie tworzenia reguł postępowania uległy istotnemu obostrzeniu wskutek wprowadzonych ustawą FTC Improvement 1980 wspomnianych już wcześniej ograniczeń proceduralnych, nade wszystko zaś

15 Szeroko na ten temat: G.T. Ford, J.E. Calfee, op. cit., s. 82-103; por. też: D. Cohen, Unfairness in Advertising revisited, J. of M. 1982, No. 1, s. 76.

1615 U.S.C. $§ 45$ (n): „The Commission shall have no authority under this section or section $57 \mathrm{a}$ of this title to declare unlawful an act or practice on the grounds that such act or practice is unfair unless the act or practice causes or is likely to cause substantial injury to consumers which is not reasonably avoidable by consumers themselves and not outweighed by countervailing benefits to consumers or to competition. In determining whether an act or practice is unfair, the Commission may consider established public policies as evidence to be considered with all other evidence. Such public policy considerations may not serve as a primary basis for such determination".

${ }_{17}$ FTC v. International Harvester Corp., 104 FTC 949, 1062 (1984); analiza sprawy w: G.T. Ford, J.E. Calfee, op. cit., s. 84, 87, 92. 
- w rezultacie wymogu przeprowadzania uprzedniej analizy efektywności, tj. rozpoznania i zmierzenia korzyści, kosztów i skutków regulacji. Wydanie określonej regulacji uzasadnione musi być nie tylko wskazaniem celu, jaki ma zostać osiągnięty, lecz także umotywowaniem zasadności realizacji tego celu właśnie drogą proponowanej regulacji, co wymaga rozpoznania rozwiązań alternatywnych oraz wykazania, że sam rynek nie może rozwiązać danego problemu, a efekty wprowadzenia regulacji przewyższą jej koszty, w szczególności - że taka ogólna regulacja jest $\mathrm{w}$ danym przypadku bardziej odpowiednia niż rozstrzygnięcia indywidual$\mathrm{ne}^{18}$. Warunki te znacznie ograniczyły aktywność Komisji w tworzeniu regulacji opartych na doktrynie nieuczciwości. Są one częścią obecnie obowiązujących przepisów i decydują o stosowanych przez Komisję procedurach.

W każdym przypadku Komisja szczegółowo analizuje przewidywane konsekwencje regulacji, ważąc koszty i korzyści oraz porównując ewentualne alternatywne rozwiązania. Przykładowo, problem aktualny: postęp technologiczny umożliwia zbieranie, gromadzenie i analizowanie m.in. w celach biznesowych ogromnego zasobu informacji on line, praktycznie bez kosztów, a przy tym - bez wiedzy zainteresowanych, którzy, pozostawiając jakąkolwiek informację czy ślad w sieci, tracą nad nim kontrolę: nie mogą jej wycofać ani zabezpieczyć przed np. sprzedaniem. Komisja, przystępując do przygotowania regulacji w sprawie praktyk marketingowych naruszających prywatność (dla potrzeb tzw. reklamy behawioralnej $)^{19}$, m.in. w Internecie, w pierwszej kolejności bada samo zjawisko, jego strony pozytywne i zagrożenia, jakie wywołuje ${ }^{20}$. W przypadku reklamy behawioralnej jako korzyści dla konsumentów wskazuje się dopasowanie reklam do ich konkretnych zainteresowań i potencjalnych potrzeb („reklama szyta na miarę"). Inną wymienianą korzyścią jest wkład takiej reklamy do finansowania treści internetowych, które $\mathrm{w}$ przeciwnym przypadku byłyby niedostępne dla konsumenta, ewentualnie - odpłatne ${ }^{21}$. ( $\mathrm{O}$ możliwie skrupulatne wyliczenie tego rodzaju argumentów pozytywnych dbają w trakcie prowadzonych konsultacji przedstawiciele zainteresowanego biznesu.) Jednocześnie - pozostając przy pro-

18 Substantial Reliable Evidence Required for FTC Rulemaking, FTC News Notes, March 2, 1984, J. of M. 1985, No. 1, s. 158; por. też: J. H. Beales, Competition, Advertising and Health Claims: Legal and Practical Limits on Advertising Regulation, „George Mason Law Review” 2004, Symposium on Antitrust and Consumer Protection, March 2, 2004.

19 W marketingu tzw. targetowanie behawioralne polega na tworzeniu reklam dobranych zależnie od profilu behawioralnego odbiorcy. Profil taki tworzony jest na podstawie odwiedzanych stron internetowych, wskazujących na zainteresowania, w szczególności dotyczące produktów i usług, oraz styl życia. Znajomość takich informacji umożliwia dopasowanie reklamy do zainteresowań poszczególnych użytkowników, co zwiększa skuteczność takiej reklamy.

20 Por. np. D.C. Vladeck, Promoting Consumer Privacy: Accountability and Transparency in the Modern World, New York University, October 2, 2009.

21 Ibidem, s. 4. 
blemie prywatności, wskazać należy zagrożenia związane z technologicznym potencjałem Internetu, umożliwiającym śledzenie ruchów internauty w sieci i gromadzenie ogromnej liczby informacji, łatwość ich przetwarzania i wykorzystania do trudnych do przewidzenia celów. Przeciwdziałanie tym zagrożeniom określa cel przygotowywanej regulacji. Tak przygotowany temat poddawany jest szerokiej konsultacji społecznej ${ }^{22}$.

Procedura konsultacji, poprzedzająca przygotowanie określonej regulacji, oczywiście wydłuża proces regulacyjny, ale zwiększa przewidywalność i zmniejsza niepewność prawa, co ma istotne znaczenie dla podmiotów gospodarczych, których dana regulacja ma dotyczyć. Często ważny jest także czas na odpowiednie dostosowanie się branży do nowych warunków działania na rynku, w tym - nierzadko - podjęcie działań samoregulacyjnych.

Przykładowo przygotowanie nowelizacji wytycznych FTC w sprawie wykorzystania rekomendacji w reklamie Guides Concerning the Use of Endorsements and Testimonials in Advertising 1980, w celu dostosowania do potrzeb współczesnego marketingu, w szczególności - uregulowania tzw. marketingu szeptanego (word of mouth marketing) ${ }^{23}$, poprzedziło wydanie przez Komisję krytycznej opinii na temat form reklamy ukrytej, w tym marketingu szeptanego (opinia z 7 grudnia 2006) ${ }^{24}$, w której Komisja odwołała się do $§ 255.5$ Guides Concerning the Use of Endorsements and Testimonials in Advertising i stwierdziła, że pewne działania są już regulowane przez prawo, w szczególności podmioty zajmujące się promocją produktów i usług przy wykorzystywaniu czyichś rekomendacji (endorsements) mają obowiązek ujawniać powiązanie tych rekomendacji z promocją, a naruszenie tego obowiązku może być podstawą postępowania Komisji. Jednocześnie jednak Komisja uznała potrzebę dopracowania zasad regulujących word of mouth marketing i wezwała branżę i zainteresowane podmioty do zgłaszania pisemnych uwag do propozycji FTC do dnia 2 marca $2009^{25}$. W wyniku przeprowadzonych konsultacji, potwierdzających zasadność aktualizacji, zmie-

22 Powoływany wyżej dyrektor Biura Ochrony Konsumenta, David C. Vladeck, podkreśla, jak ważne z punktu widzenia skuteczności działania Komisji jest odpowiednie utrafienie w moment czasowy; daje przykład, że o stopniu zainteresowania i kierunku dyskusji na temat problemu prywatności zadecydował fakt, iż został on przedstawiony opinii publicznej w październiku 2007 r., akurat po tym, jak Facebook wprowadził program Beacon, śledzący aktywność użytkowników Facebooka na innych witrynach. (Wobec zagrożenia procesem sądowym, Facebook ogłosił w 2009 r. plan zamknięcia programu Beacon.) D. C. Vladeck, op. cit., s. 5.

23 Szerzej: A. Mokrysz-Olszyńska, Komunikacja nieformalna w marketingu a zakaz reklamy ukrytej, „Zeszyty Naukowe Kolegium Gospodarki Światowej” nr 27, SGH, Warszawa 2010, s. 79 i n.

24 A. Shin, FTC Moves to Unmask Word-of-Mouth Marketing, „Washington Post”, December 12, 2006, s. D01, http://www.washingtonpost.com/wp-dyn/content/article/20061211013.

25 VaGla, W USA zakończyly się konsultacje FTC w sprawie WOMM, http://prawo.vagla.pl/ node/8424; por. też: M. E. Podmolik, Federal Trade Commission's plan to change rules on ad endorse- 
niona regulacja Guides Concerning the Use of Endorsements and Testimonials in Advertising weszła w życie $\mathrm{z}$ dniem 1 grudnia 2010 roku, jednak już w marcu 2009 r. stowarzyszenie agencji zajmujących się marketingiem szeptanym (The Word of Mouth Marketing Association - WOMMA) przyjęło kodeks etyczny (WOMMA Etbics Code), nad którym prace prowadzono równolegle z działaniami Komisji, od 2006 roku$^{26}$.

Po konsultacjach, kolejnym etapem poprzedzającym wprowadzenie regulacji jest dokonanie analizy kosztów i korzyści, jakie może przynieść planowana regulacja, w szczególności: dającej odpowiedź na pytanie o to, czy regulacja prowadzi do osiągnięcia zamierzonego celu oraz czy osiągnięcie tego celu nie jest możliwe za pomocą innego, bardziej efektywnego (mniej restrykcyjnego) środka.

Tak na przykład, zgodnie z tzw. doktryną komunikacji handlowej (Commercial Speech Doctrine), jeśli komunikacja handlowa (np. reklama) nie jest ani myląca (wprowadzająca w błąd), ani nie narusza przepisów prawnych, Komisja musi wykazać, że regulacja ograniczająca komunikację: po pierwsze, uzasadniona jest istotnym interesem publicznym; po drugie, bezpośrednio zmierza do określonego celu oraz, po trzecie, nie jest szersza ani bardziej restrykcyjna, aniżeli jest to konieczne do zabezpieczenia tego interesu. Wymienione trzy warunki, sformułowane przez Sąd Najwyższy w orzeczeniu z 1980 r. uchylającym regulację zakazującą prowadzenia reklamy promocyjnej przez dostawców energii elektrycznej ${ }^{27}$, stanowią treść tzw. testu Central Hudson (Central Hudson test). Ich łączne spełnienie w praktyce często sprawia trudności. Przykładowo, w analizie regulacji zmierzającej do ograniczenia kierowanej do dzieci reklamy telewizyjnej wysokokalorycznych produktów stosunkowo łatwo było wykazać, że ochrona zdrowia dzieci (wobec występowania w społeczeństwie amerykańskim plagi otyłości, poczynając od dzieci) stanowi istotny interes publiczny. Znacznie trudniej jednak udowodnić występowanie związku między telewizyjną reklamą a zdrowiem dzieci, tj. zależności między oglądalnością przez dzieci reklam w telewizji a wzrostem konsumpcji wysokokalorycznych produktów (warunek drugi). Faktycznie, szeroko prowadzone badania empiryczne nie dały w tej kwestii jednoznacznej odpowiedzi ${ }^{28}$. Podobnie trudne okazało się spełnienie trzeciego warunku, tj. wykazania, że regulacja nie jest szersza ani bardziej restrykcyjna niż to konieczne do zabezpieczenia

ments, testimonials worries marketers, „Consumerist”, March 20, 2009, http://www.freerepublic.com/ focus/f-news/2212988/posts.

26 http://womma.org/ethics/ethicscode.pdf.

27 Central Hudson Gas E Electric Corp. v. Public Serv. Commission, 447 U.S. 556 (1980).

28 Co były przewodniczący FTC, Timothy J. Muris, skwitował: „Nawet nasze psy i koty są tłuste, choć przecież nie z tego powodu, że oglądają za wiele reklam" - podaję za: C.J. Jennings, M. Koebel Engle, Advertising to Kids and the FTC: A Regulatory Retrospective That Advises the Present, s. 20 (przypis 101). 
chronionego interesu. Wymagałoby to bowiem porównania skuteczności innych wchodzących w grę środków (takich jak np. edukacja w szkołach, promowanie zdrowego żywienia wśród rodziców, ograniczenia sprzedaży „żywności śmieciowej” w szkolnych sklepikach itp.), których poszczególnego wpływu nie sposób wyabstrahować w badaniu, a co za tym idzie - zmierzyć i porównać skuteczności. W rezultacie podejmowane przez Komisję od wielu lat próby rozwiązania problemu niewłaściwych nawyków żywieniowych u dzieci przez regulację ograniczającą reklamę wysokokalorycznych produktów w telewizji nie odniosły sukcesu ${ }^{29}$.

Alternatywą regulacji, która jest uwzględniana ze szczególną uwagą, jest możliwość rozwiązania danego problemu w drodze samoregulacji. Federalna Komisja Handlu ma za sobą kilkudziesięcioletnie doświadczenie w organizowaniu samoregulacji biznesu. Komisja realizuje ją poprzez tzw. Konferencję Praktyki Handlowej (Trade Practice Conference), działającą w zależności od potrzeb, z udziałem przedstawicieli zainteresowanych branż i środowisk biznesowych. $Z$ inicjatywy Konferencji opracowane zostały i przyjęte w ramach samodyscypliny zbiory zasad dobrych praktyk rynkowych (kodeksy), rozwiązujące niektóre bardziej typowe problemy. W szczególności, wobec wyżej wspomnianych trudności we wprowadzeniu regulacji ograniczającej reklamy telewizyjne produktów wysokokalorycznych, Komisja podjęła działania na rzecz wprowadzenia stosownych rozwiązań w drodze samoregulacji, zapoczątkowane opublikowaniem w kwietniu 2006 raportu, zawierającego rekomendacje różnych rozwiązań, poczynając od edukacji społeczeństwa nt. zasad prawidłowego żywienia, propagowania zdrowej żywności, po ograniczenia reklamy wyłącznie do produktów żywnościowych spełniających kryteria zdrowotne. W następstwie raportu, w 2006 roku Rada Better Business Bureaus $^{30}$ przyjęła Inicjatywę dotyczącą Kierowanej do Dzieci Reklamy Żywności i Napojów (Children's Food and Beverage Advertising Initiative 2006), do której przyłączyła się większość liczących się na rynku przedsiębiorstw branży spożywczej, deklarując rezygnację z reklamy kierowanej do dzieci poniżej 12 lat lub generalne ograniczenie takiej reklamy wyłącznie do produktów spełniających kryteria żywieniowe ${ }^{31}$.

Aktualnym przykładem aktywnego współdziałania Komisji z biznesem w sprawie wprowadzenia możliwie skutecznej samoregulacji jest omawiany wyżej problem ochrony prywatności w kontekście reklamy behawioralnej. Niezależnie

\footnotetext{
29 Ibidem.

30 System Better Business Bureaus, z Radą na czele, stanowi główną organizację formalnej samoregulacji biznesu w Stanach Zjednoczonych - www.bbb.org/.

31 Children's Food and Beverage Advertising Initiative Issues Statement on the White House Task Force on Childhood Obesity Report, 11.05.2010, http://www.bbb.org/us/article/childrens-food-andbeverage-advertising-initiative-issues-statement-on-the-white-house-task-force-on-childhoodobesity-report-19478.
} 
od kontynuowania prac nad przygotowaniem regulacji w tym zakresie, oraz równolegle do podejmowanych interwencji w sprawach indywidualnych ${ }^{32}$, Komisja zaproponowała określone zasady samoregulacji: każda strona internetowa zbierająca informacje dla celów marketingowych (reklamy behawioralnej) powinna o tym poinformować konsumentów i dać im wybór co do wyrażenia lub odmowy zgody na takie zbieranie; wszelkie informacje i objaśnienia na ten temat powinny być łatwe do znalezienia i zrozumienia. Podmiot, który gromadzi dane dla celów reklamy behawioralnej, powinien zastosować rozsądne zabezpieczenia, w zależności od stopnia wrażliwości danych i charakteru operacji biznesowych i przechowywać dane tylko tak długo, jak to konieczne do spełnienia uzasadnionego celu handlowego. Powinien on uzyskać potwierdzającą zgodę konsumenta na wszelkie zmiany w polityce dotyczącej zbioru danych; musi dotrzymywać wszystkich wcześniejszych zobowiązań i obietnic, nawet jeśli ta polityka ulegnie zmianie. Wreszcie - zbieranie dla celów reklamy behawioralnej danych wrażliwych może występować wyłącznie na podstawie wyrażnie wyrażonej przez konsumenta zgody ${ }^{33}$. Formułując takie warunki, Komisja deklaruje poparcie dla rozwijania specyficznych standardów samoregulacji w celu powstrzymania praktyk „problematycznych”, jednocześnie podkreślając, że w razie braku osiągnięcia satysfakcjonujących rozwiązań na tej drodze Komisja podejmie dalsze kroki w kierunku wprowadzenia regulacji i egzekwowania ${ }^{34}$.

Oprócz analizy ex ante, Komisja prowadzi monitoring regulacji po jej wprowadzeniu, a po określonym czasie jej obowiązywania - przeprowadza analizę jej skutków i skuteczności ex post. Analiza taka może być podstawą podejmowania dalszych działan, np. wprowadzenia odpowiednich zmian dostosowawczych. Przykładowo, regulacja dotycząca telemarketingu wraz z centralnym rejestrem Do Not Call została wprowadzona w 2003 roku, początkowo z założeniem, że wpisy do rejestru wygasną po 5 latach. Jednak prawie entuzjastyczne przyjęcie

32 Jedna z ostatnich głośnych spraw rozpatrywanych przez Komisję dotyczyła Sears Holding Corp. Według oskarżenia Komisji Sears płaciła konsumentom 10 w zamian za zainstalowanie oprogramowania rejestrującego „w celach badawczych” przeglądane strony internetowe. Faktycznie program zbierał ogromny zakres informacji, w tym zawartość kart płatniczych, korespondencji bankowej, recept lekarskich oraz objętość, adresatów i nadawców korespondencji mailowej. Uznając taki zakres zbieranej informacji za daleko wykraczający poza potrzeby badania marketingowego, Komisja wystosowała consent order $\mathrm{z}$ wezwaniem do zaprzestania zbierania informacji za pomocą zainstalowanego oprogramowania i zniszczenia wszystkich zgromadzonych dotychczas w ten sposób danych. Kierownictwo Sears Holding Corp. podpisało consent order 9 września 2009 r. - Sears Holdings Corp., FTC Dkt. Nr C-4264; podaję za: D.C. Vladeck, op. cit.

${ }_{33}$ Federal Trade Commission, Self-Regulatory Principles for Online Behavioral Advertising, February 2009, http://www2.ftc.gov/os/2009/02/P085400behavadreport.pdf.

${ }_{34}$ A Look Forward With the FTC: Advertising and Marketing Enforcement Challenges, Remarks of David C. Vladeck, Director, FTC Bureau of Consumer Protection, on Electronic Retailing Association, Great Ideas Summit, New Orleans, LA, February 3, 2010, s. 30. 
tej koncepcji przez konsumentów (wg stanu ze stycznia 2010 roku w Rejestrze figuruje 191 milionów numerów) ${ }^{35}$ oraz opinie konsumentów o zdecydowanym zredukowaniu liczby niechcianych telefonów marketingowych dały podstawę mimo głośnych protestów ze strony biznesu telemarketingowego, powołującego się na utratę zysków i miejsc pracy (wcześniej roczne zyski tej branży notowały poziomy ponad 600 miliardów dolarów) ${ }^{36}$ - do wydania w 2007 r. regulacji uzupełniającej Do Not Call Improvement Act 2007, nadającej wpisom charakter ciągły i bezterminowy. Rachunek „strat i zysków” systemu Do Not Call obejmuje także kwotę 22 mln dol. kar, uzyskaną przez Federalną Komisję Handlową i Federalną Komisję Komunikacyjną z tytułu kar nałożonych za niezastosowanie się do Rejestru ${ }^{37}$. W uzupełnieniu systemu Do Not Call Komisja przyjęła w roku 2010 regulację zmieniającą Telemarketing Sales Rule, która obowiązuje od 1 września 2010 i zakazuje tzw. robocalls, tj. telefonów z wcześniej nagranym tekstem komercyjnym, o ile telemarketer nie otrzyma wcześniej pisemnej zgody konsumenta na otrzymywanie takich telefonów. Za złamanie tego zakazu grozi kara do 16 tys. dol. za rozmowę.

Warto zauważyć, że nie tylko sama procedura postępowania przy tworzeniu regulacji, ale także dobór środków jej egzekwowania naznaczony jest podejściem „efektywnościowym”: z założenia mają to być środki skuteczne, gwarantujące osiągnięcie celu regulacji, a więc np. dostatecznie odstraszające, skutecznie powstrzymujące pokusę uzyskania zysków poprzez działania naruszające daną regulację. W tym zakresie szczególnie przydatne są metody analizy ekonomicznej.

\section{MOŻLIWOŚĆ I CELOWOŚĆ ZASTOSOWANIA W PRAWIE KONSUMENCKIM METOD ANALIZY EKONOMICZNEJ - PRÓBA OCENY}

Obserwacja działalności Federalnej Komisji Handlu na przestrzeni prawie wieku wskazuje, że ochrona konsumentów udzielana w interesie publicznym mieści się w szerszym obszarze regulacji działalności rynkowej. Regulacja ta ma na celu zapewnienie sprawnego funkcjonowania rynku, a ochrona interesów uczestników działalności rynkowej, w szczególności - konsumentów, podobnie jak ochrona

35 FTC Approves Two Reports to Congress on the National Do Not Call Registry, http://www.ftc. gov/opa/2010/01/donotcall.shtm.

${ }_{36}$ Ch. Parry, The FTC and the Economy, http://www.investorguide.com/igu-article-941-government-regulations-the-ftc-and-the-economy.html.

37 Wg informacji szefa Biura Ochrony Konsumenta, Davida C. Vladecka podanej na zjeździe Stowarzyszenia Elektronicznego Handlu Detalicznego w Nowym Orleanie, 3 lutego 2010: A Look Forward. 
samego mechanizmu konkurencji, w istocie rzeczy podporządkowana jest realizacji celu głównego. Realizując ten cel, regulacja określa zakres swobody działalności rynkowej, przy zachowaniu generalnej zasady minimalizowania ingerencji w mechanizmy rynkowe, a jednocześnie tworzy system zachęt i bodźców dla uczestników rynku. System ten od początków działania Komisji nacechowany jest dążeniem do rozwiązań efektywnych - w sensie ekonomicznym, gdzie efektywność (najogólniej) mierzona jest stosunkiem korzyści (zysków) do nakładów (kosztów). Najwcześniejszym wyrazem - i podłożem - takiego nastawienia jest zasada rozsądku (słuszności): rule of reason, przyjęta jako kryterium oceny praktyk ograniczających konkurencję ${ }^{38}$. W rezultacie właśnie na gruncie prawa antytrustowego rozwinęły się podstawy kierunku ekonomicznej analizy prawa (Law E Economics); kierunku, którego istota polega na badaniu wpływu przepisów prawa na kształtowanie się relacji rynkowych, rządzących się obiektywnymi prawami ekonomii, w szczególności - przy zastosowaniu metod i narzędzi ekonomicznych $^{39}$. W latach sześćdziesiątych metody analizy ekonomicznej zaczęto stosować w Stanach Zjednoczonych także w odniesieniu do innych dziedzin prawa ${ }^{40}$, a od 1980 r. elementy takiej analizy stały się obowiązkową procedurą w rozwijaniu przez Federalną Komisję handlu pojęcia unfair acts or practices in or affecting commerce, stanowiącej ogólną podstawę ochrony interesów konsumentów.

Warto podkreślić, że zasadność ekonomiczna zwalczania praktyk wprowadzających w błąd (deceptive) traktowana jest jako oczywista: wprowadzenie w błąd rozumiane jako doprowadzanie do podejmowania przez konsumentów takich decyzji rynkowych, których przy właściwym rozpoznaniu oferty rynkowej nie podjęliby, stanowi nie tylko przejaw bezpośredniego naruszania interesów konsumentów, ale jednocześnie powoduje zakłócenie relacji konkurencyjnych i przechwytywanie klientów kosztem uczciwych konkurentów. Funkcjonowanie mechanizmu konkurencji jest uwarunkowane przejrzystością (transparencją) rynku;

38 Zasada przyjęta w sprawie: Standard Oil Co. of New Jersey et al. v. United States, 221 U.S. $1 / 1911$.

39 W literaturze występują różne definicje ekonomicznej analizy prawa (Law E̊ Economics). Autorzy przekładu podręcznika R. Cootera i Th. Ulena, Ekonomiczna analiza prawa, wyd. C.H. Beck, Warszawa 2009, dokonują podziału tych definicji na te, które przybliżają przedmiot (badanie wpływu ustanowionych sankcji prawnych na zachowania ludzi) oraz te, które odnoszą się do stosowanej metody badawczej. Przykładowo, definicja przyjęta przez L. Balcerowicza podkreśla, że Law Ẻ Economics odnosi się do analizy rozwoju i ekonomicznych skutków różnych rozwiązań prawnych (L. Balcerowicz, Systemy gospodarcze. Elementy analizy porównawczej, Warszawa 1993, s. 8) - podaję za: R. Cooter, Th. Ulen, op. cit., s. XVII.

40 Przełomowe znaczenie miała publikacja R.H. Coase, The Problem of Social Cost, "Journal of Law and Economics" 1960, No. 3, a następnie G. Calabresi, Some Thoughts on Risk Distribution and the Law of Torts, „Yale Law Journal” 1961, vol. 70 - podaje za: R. Cooter, Th. Ulen, op. cit., s. 2 oraz 101 i n. (twierdzenie Coase'a). 
stąd potrzeba zabezpieczenia transparentności rynku jest dostatecznym uzasadnieniem dla wprowadzania regulacji w zakresie deception.

Zastosowanie metod analizy ekonomicznej w rozwiązywaniu konkretnych problemów z zakresu ochrony konsumentów przez Federalną Komisję Handlu odnosi się zatem głównie do obszaru interpretacji pojęcia unfairness; jak pokazuje praktyka - z różnymi rezultatami.

Aby ocenić przydatność ekonomicznej analizy prawa (eap) w zakresie ochrony konsumentów, należy przede wszystkim zdać sobie sprawę z istoty tego instrumentu. Podstawą eap jest odwołanie się do teorii ekonomicznych w celu określenia podstawowych zależności między analizowanymi zmiennymi (czyli czynnikami, które ulegają zmianom wskutek działania określonego bodżca zewnętrznego, np. danej regulacji), a metoda polega na zbudowaniu modelu, tworzącego uproszczony obraz rzeczywistości. Ujęcie modelowe wymaga przyjęcia określonych założeń. Podstawowym założeniem neoklasycznej ekonomii i opartej na niej eap w ujęciu tzw. szkoły chicagowskiej jest założenie racjonalności wyborów dokonywanych przez podmioty działające na rynku, a więc zarówno przedsiębiorstwa, jak i konsumentów, maksymalizujące swoje korzyści w warunkach pełnej informacji oraz braku umyślnej nielojalności. W literaturze sporo miejsca poświęcono zakłóceniom, wskutek których rzeczywistość odbiega od założeń ${ }^{41}$; zresztą ,jeśli model racjonalnego zachowania rynkowego byłby prawdziwy, swoboda umów gwarantowałaby stronom optymalne rozwiązanie, a interwencja państwa byłaby zbędna"42 - jak spostrzega Michael Salinger, dyrektor Biura Ekonomicznego FTC w latach 2005-2007. Tenże M. Salinger, analizując bezskuteczne próby rozwiązania problemu otyłości u dzieci za pomocą ograniczenia telewizyjnej reklamy wysokokalorycznych produktów, wprost stwierdza: „Po prostu nie można czynić wyszukanych analiz w odniesieniu do praktyk marketingowych stosowanych przez firmy bez wychodzenia poza świat racjonalnego postępowania, doskonałej informacji i zerowych kosztów transak-

${ }^{41} \mathrm{Na}$ temat eap w literaturze polskiej m.in R. Stroiński, Ekonomiczna analiza prawa czyli w poszukiwaniu efektywności, „Kwartalnik Prawa Prywatnego” 2002 z. 3, s. 549 i n.; idem, Wprowadzenie do ekonomicznej analizy prawa (Law and Economics), [w:] Ekonomia dla prawników i nie tylko, red. M. Bednarski i J. Wilkin, wyd. IV, Warszawa 2008; J. Bełdowski, K. Metelska-Szaniawska, Law E Economics - geneza i charakterystyka ekonomicznej analizy prawa, „Bank i Kredyt”2007, nr 10, s. 51 i n.; M. Sośniewiecka (red.), J. Stelmach (red.), Analiza ekonomiczna w zastosowaniach prawniczych, Warszawa 2007; J. Stelmach, B. Brożek, W. Załuski, Dziesięć wykładów o ekonomii prawa, Warszawa 2007; P. Mikłaszewicz, Obowiązki informacyjne w umowach z udziatem konsumentów na tle prawa Unii Europejskiej, Oficyna a Wolters Kluwer business, Warszawa 2008, rozdz. II pt. „Ekonomiczna analiza obowiązków informacyjnych”, s. 52-81; bogata literatura obca i liczne czasopisma - zestawienie patrz np. Law and Economics Resources, http://lawecon.lp.findlaw.com.

42 M. Salinger, Behavioral Economics, Consumer Protection and Antitrust, A Symposium on Antitrust \& Behavioral Economics, Lexis Nexis, Documents, Competition Policy International, Spring 2010, s. 3. 
cyjnych. Wyzwanie dotyczy rozluźnienia standardowych założeń ekonomicznych przy zachowaniu istoty fundamentalnych zasad"43.

W kierunku spełnienia tego postulatu wydają się prowadzić badania w ramach tzw. ekonomii behawioralnej ${ }^{44}$. W ekonomii behawioralnej założenie racjonalności zastępują modele ograniczonej racjonalności (bounded rationality), uwzględniające to, że większość ludzi tylko częściowo kieruje się motywami racjonalnymi, a w znacznej części - emocjonalnymi i irracjonalnymi; racjonalność jednostek jest ograniczona przez zasób posiadanych informacji, ograniczenia poznawcze i skończoną ilość czasu, w której podejmują decyzje. Proponując analizy rynku uwzględniające zarówno poinformowanych, jak i niepoinformowanych konsumentów, dążące do wyjaśnienia prawdziwych przyczyn wyborów konsumentów, ekonomia behawioralna wydaje się bardziej odpowiednia dla potrzeb analizy prawa konsumenckiego. Nie oznacza to jednak, że modele uwzględniające więcej czynników są już odpowiednim odzwierciedleniem rzeczywistości; ta bowiem jest nadal nieporównanie bardziej złożona. „Sceptycyzm co do podejścia behawioralnego wynika nie tyle $\mathrm{z}$ braku wiary w racjonalność ludzi, ile $\mathrm{z}$ uznania, że źródła nieracjonalności są bogate - znacznie bogatsze aniżeli te, które wymienia literatura ekonomii behawioralnej" ${ }^{5}$.

Analiza ekonomiczna prawa nie ogranicza się do objaśnienia zjawisk ekonomicznych i wpływu norm prawnych na funkcjonowanie gospodarki (kierunek pozytywny); próbuje wartościować rozwiązania, które mają na celu naprawianie niedoskonałości rynku, uznając jedne za bardziej pożądane od innych (kierunek normatywny). Jej wyniki mają decydować zatem o wpływie na politykę gospodarczą i właśnie to jest źródłem kontrowersji. Zarówno w w prawie antytrustowym, jak i w ochronie konsumenta zastosowanie standardów analizy ekonomicznej ma, w założeniu, ograniczać zakres interwencji państwa. Zainteresowanie ekonomią behawioralną wypływa poniekąd $\mathrm{z}$ wiary, że usprawiedliwi ona szerszy zakres takiej interwencji. „Proponenci widzą ekonomię behawioralną jako antidotum na truciznę szkoły chicagowskiej. Oponenci - jako zmutowaną bakterię, odporną na lekarstwo ekonomii, niezbędne do prowadzenia właściwej polityki" ${ }^{46}$, stwierdza cytowany wyżej Michael Salinger. Z pozycji byłego dyrektora Biura Ekonomicznego FTC ocenia, że ekonomiczna analiza prawa faktycznie odgrywa znacznie

43 Idem, Consumer Protection Economics at the FTC. Prepared Remarks for Chief Economist Roundtable, Boston, Massachusetts, April 8, 2006, s. 2.

44 Ekonomia behawioralna jest młodą (jej początki to okres lat 80. ubiegłego wieku), szybko rozwijającą się dziedziną, która, łącząc dorobek teorii mikroekonomiczych z badaniem zachowań ludzkich, dąży do wyjaśnienia przyczyn preferencji konsumentów; por.: W. Białaszek, Pomiędzy ekonomiq i psychologiq. Ekonomia behawioralna w ujęciu analizy zachowania, http://www.ptpb.pl/www/ index.php/publisher/articleview/frmArticleID/42/.

45
46
Ibidem, s. 1. 
mniejszą rolę w ochronie konsumenta aniżeli w prawie antytrustowym, a przyczynę tego dostrzega $\mathrm{w}$ tym, że ekonomia behawioralna nie jest dostatecznie rozwinięta, aby mogła sprostać temu zadaniu ${ }^{47}$. Jako przykład powołuje zjawiska, które wywołały ostatni kryzys finansowy, stawiając jednocześnie pytanie o to, czy był on do uniknięcia przy bardziej zdecydowanej polityce ochrony konsumentów na rynku finansowym. Wskazuje przy tym na ujawnienie się w łańcuchu przyczynowo-skutkowym szeregu takich odstępstw od zasady racjonalnego działania, które nie zostały dotąd zidentyfikowane w literaturze ekonomii behawioralnej: dlaczego kredyty były udzielane osobom, które nie rokowały szans na ich spłacenie, zwłaszcza przy - nietrudnym do przewidzenia! - odwróceniu się trendu wzrostowego cen nieruchomości; dlaczego główne agencje ratingowe nie doszacowały ryzyka itp. Wniosek, jaki wyprowadza, zamyka się w stwierdzeniu, że to właśnie brak regulacji stał się przyczyną tego, że ,jednostki mogły działać bez ograniczeń zgodnie $z$ modelem opartym na własnym interesie, wedle reguły: ja zyskuję, ty tracisz"48.

Ta konstatacja powinna służyć za przestrogę w szczególności tym, którzy za pomocą czystej kalkulacji ekonomicznej, siłą rzeczy - jednostronnej, wycinkowej, a przy tym opartej na nie do końca wiarygodnych danych, usiłują uzasadniać określoną regulację względnie - co częstsze: potrzebę deregulacji. Uświadomienie sobie ograniczonej wiarygodności wyników kalkulacji opartej na uproszczonych rozwiązaniach modelowych - jak się okazuje, nawet w odniesieniu do zjawisk w znacznej mierze kwantyfikowalnych, jak w sferze finansowej - każe z dużym sceptyzmem traktować przydatność modeli ekonomicznych w zakresie ochrony konsumentów.

\section{ZAKOŃCZENIE}

Ekonomiczna analiza prawa, jako narzędzie badania skutków danej regulacji z perspektywy reguł ekonomicznych, jest, na obecnym etapie jej możliwości, narzędziem niedoskonałym, choć w obszarze regulacji działalności rynkowej - niewątpliwie pożądanym; jeśli zaś traktować ochronę interesów zbiorowych konsumenta jako element i pochodną ochrony systemu rynkowego, wtedy także w tym obszarze - przydatne. Ważenie różnych, często sprzecznych interesów na szali kosztów i zysków, aby wynik był prawidłowy (zbliżony do prawidłowego), musi uwzględniać możliwie wszystkie elementy i interakcje - a to jest trudne, jeśli w ogóle możliwe; z drugiej strony - właśnie metody ekonomicznej analizy dają

47 Ibidem, s. 10.

48 Ibidem, s. 10-11. 
szansę odkrywania źródeł niedoskonałości rynku i mogą być wykorzystane do znajdowania sposobów ich eliminowania. W istocie, ekonomiczna analiza może prowadzić nie tylko do ograniczania, ale i stymulować ochronę konsumentów. Skoro zatem jest do dyspozycji narzędzie przydatne, na swój sposób - właściwe, acz niedoskonałe (i nie uniwersalne!) - nie należy go odrzucać, lecz doskonalić, a stosować z pełną świadomością jego ograniczeń.

\section{BIBLIOGRAFIA}

A Look Forward With the FTC: Advertising and Marketing Enforcement Challenges, Remarks of David C. Vladeck, Director, FTC Bureau of Consumer Protection, on Electronic Retailing Association, Great Ideas Summit, New Orleans, LA, February 3, 2010.

Annys Shin, FTC Moves to Unmask Word-of-Mouth Marketing, Washington Post, December 12, 2006, s. D01, http://www.washingtonpost.com/wp-dyn/content/article/20061211013

Beales J. H., Competition, Advertising and Health Claims: Legal and Practical Limits on Advertising Regulation, George Mason Law Review 2004, Symposium on Antitrust and Consumer Protection, March 2, 2004.

Białaszek W., Pomiędzy ekonomiq i psychologiq. Ekonomia behawioralna w ujeciu analizy zachowania, http://www.ptpb.pl/www/index.php/publisher/articleview/frmArticleID/42/

Boddewyn J., Advertising Regulation in the 1980's: the underlying Global Forces, "Journal of Marketing" (dalej: J. of M.) 1982, No. 1.

Brandt K.T., Preston J.L., The Federal Trade Commission's Use of Evidence to Determining Deception, J. of M. 1977, No. 1.

Calabresi G., Some Thoughts on Risk Distribution and the Law of Torts, „Yale Law Journal” 1961.

Coase R.H., The Problem of Social Cost, „Journal of Law and Economics” 1960, No. 3.

Cohen D., Remedies for Consumer, Protection: Prevention, Restitution or Punishment, J. of M. 1975, No. 4

Cohen D., The Concept of Unfairnessas it relates to Advertising Legislation, J. of M. 1974, No. 3.

Bełdowski J., Metelska-Szaniawska K., Law E Economics - geneza i charakterystyka ekonomicznej analizy prawa, „Bank i Kredyt” 2007, nr 10.

Cohen D., Unfairness in Advertising revisited, J. of M. 1982, No. 1.

Cooter R., Ulen Th. Ekonomiczna analiza prawa, wyd. C.H. Beck, Warszawa 2009

Federal Trade Commission, Self-Regulatory Principles for Online Behavioral Advertising, February 2009, http://www2.ftc.gov/os/2009/02/P085400behavadreport.pdf.

Ford G.T., Calfee J.E., Recent Development in FTC Policy on Deception, J. of M. 1986, No. 2. 
FTC Approves Two Reports to Congress on the National Do Not Call Registry, http://www. ftc.gov/opa/2010/01/donotcall.shtm.

How the FTC brings an action, http://www.ftc.gov/pbc/conline/pubs/general/guidetoftc. shtm.

http://ftc.gov/

Jennings C.J., Koebel Engle M., Advertising to Kids and the FTC: A Regulatory Retrospective That Advises the Present.

Law and Economics Resources, http://lawecon.lp.findlaw.com/.

Mikłaszewicz P., Obowiqzki informacyjne w umowach z udziatem konsumentów na tle prawa Unii Europejskiej, Oficyna Wolters Kluwer business, Warszawa 2008.

Miller J., Unfair Competition, Cambridge 1941.

Mokrysz-Olszyńska A., Komunikacja nieformalna w marketingu a zakaz reklamy ukrytej, „Zeszyty Naukowe Kolegium Gospodarki Światowej”, z. 27. SGH, Warszawa 2010.

Muris T.J., Pitofsky R., More than Law Enforcement: The FTC's Many Tools - A Conversation with Tim Muris and Bob Pitofsky, „Antitrust Law Journal” 2005, vol. 72, No. 3.

Parry Ch., The FTC and the Economy, http://www.investorguide.com/igu-article-941-government-regulations-the-ftc-and-the-economy.html.

Podmolik M.E., Federal Trade Commission's plan to change rules on ad endorsements, testimonials worries marketers, "Consumerist", March 20, 2009, http://www.freerepublic. com/focus/f-news/2212988/posts.

Salinger M., Behavioral Economics, Consumer Protection and Antitrust, A Symposium on Antitrust \& Behavioral Economics, Lexis Nexis, Documents, Competition Policy International, Spring 2010.

Salinger M., Consumer Protection Economics at the FTC. Prepared Remarks for Chief Economist Roundtable, Boston, Massachusetts, April 8, 2006, s. 2.

Sośniewiecka M., Stelmach J. (red.), Analiza ekonomiczna w zastosowaniach prawniczych, Warszawa 2007.

Stern L.W., Eovaldi T.L., Legal Aspects of Marketing Strategy, Antitrust and Consumer Protection Issues, Englewood Cliffs, New Jersey 1984.

Stroiński R., Ekonomiczna analiza prawa czyli w poszukiwaniu efektywności, „Kwartalnik Prawa Prywatnego" 2002, z. 3.

Stroiński R., Wprowadzenie do ekonomicznej analizy prawa (Law and Economics), [w:] Ekonomia dla prawników i nie tylko, red. M. Bednarski, J. Wilkin, wyd. IV, Warszawa 2008.

Substantial Reliable Evidence Required for FTC Rulemaking, FTC News Notes, March 2, 1984, J. of M. 1985, No. 1.

The Federal Trade Commission Act 1914 http://www.stolaf.edu/people/becker/antitrust/ statutes/ftc.html.

VaGla (Waglowski P.), W USA zakończyty się konsultacje FTC w sprawie WOMM, http:// prawo.vagla.pl/node/8424.

Vladeck D.C., Promoting Consumer Privacy: Accountability and Transparency in the Modern World, New York University, October 2, 2009. 


\section{UNFAIRNESS DOCTRINE AND THE ECONOMIC APPROACH \\ TO CONSUMER PROTECTION IN THE PRACTICE OF THE FEDERAL TRADE COMMISSION IN THE U.S.}

SUMMARY

Starting from the concept of treating the protection of consumers'interests as a necessary element of market order, the U.S. federal law has created a pattern of protection against unfair or misleading acts or market practices, perceived from the perspective of their effects on consumers, competitive relationships, and the functioning of the market mechanism. Such a comprehensive perspective justifies the economic approach to the regulation of unfair market practices. At the same time, it is intriguing to search for answers to the question of the possibility and desirability of applying elements of economic analysis of law with respect to the interpretation of unfairness to the consumer (unfairness doctrine). 
